\title{
Some microbial treatments against the tomato leaf miner; Tuta absoluta (Merick) under natural field conditions
}

\author{
Amira S. Mohammed and *Nagwa M. M. El-Khatteeb **Ezzat Ahmed \\ Entomology Department, *Botany Department Faculty of Agriculture, Kaferelsheikh University. Egypt. \\ **University of Debrecen Centre of Agricultural Science and Engineering Institute for Research and \\ Development, Hungary
}

\begin{abstract}
In an attempt to find more effective methods and safety to control the tomato leaf miner, Tuta absoluta, this research was conducted to study the efficacy of the four bio-treatments ; two bacterial isolates (Bacillus subtilis. and Pseudomonas Fluorescence), one fungal isolate (Trichoderma viride) and Spinosad as a microbial insecticide compared with the most common insecticides used against the dipterous and lepidopterous leaf miners in Egypt; Profenofos and Aphox. In the two successive seasons; 2011 and 2012, the fungal isolate Trichoderma viride achieved the lowest infestation(numbers of infested leaflets, mines, infestation percentages) which were 167, 195, and 21.9\% resp.in season 2011 and 198, 222 and 26.2\% resp. in season 2012. While the highest infestation was occurred in case of using the insecticides, Aphox (423, 559 and 55.9\% resp.\& 384, 839 and 72.2\%. and Prohpenofos (436, 562 and 57.7\% \&391, 534 and $51.7 \%$ resp.).during 2011 and 2012 respectively. The other treatments occupied the intermediate levels.

On the other hand, the yield of tomato fruits was increased by $75 \%$ over the check in case of plants treated with Trichoderma viride isolate, but the pesticide treatment given weak or no impact in increasing tomato crop.

In season 2012, the infested tomato fruits percentages with T. absoluta larvae and Rhizoctonia soil rot disease(that Frequently observed incidentally) were recorded the minimum levels obtained by spraying Trichoderma viride isolate(21.38 and 10.32\% resp.). In contrast, the maximum levels were recorded in Prophenofos (44.87 and22.78\% resp.) and Aphox treatments(47.22 and 27.78\% resp.).
\end{abstract}

Keywords: tomato

\section{Introduction}

Chemical control has been the main method of control used against T. absoluta in all tomato production regions in Argentina since 1970. Horticultural growers have tried to decrease its injure applying insecticides two times a week during a single cultivation period. Effective chemical control was difficult to achieve because of the mine-feeding behavior of larvae, lack of a threshold action, and deficient spraying technology (Marcela et. al., 2005).In addition to destruction of natural enemy populations (Campbell et al.,1991), build up of insecticide residues on tomato fruits (Walgen bach et al.,1991) and in the environment and fundamentally the rapid development of insecticide resistance (Siquira et al.,2000a and Siquira et al.,2000b).

Common insect pathogens used against insectpests according to Weinzierl, 1989 are Bacillus thuringiensis, B.popilliae, B.lentimorbus (bacterial pathogens) and Baeuvaria bassiana (fungal pathogen).

This investigation was carried out in the experimental farm at the faculty of Agricultural, Kafr El-Sheikh University during the two successive seasons 2011 and 2012 to study the following aims:

1. The effect of some uncommon bio- treatments used to control the tomato leaf miner; Tuta absoluta (Meyrick) infesting tomato plants.
2. Evaluating the percentages of infested tomato fruits by T. absoluta larvae in the tested treatments.

\section{Materials and methods}

\section{Feild studies}

Field experiments were carried out at the experimental farm of the Faculty of Agriculture, Kafr El-Sheikh University during two successive seasons ; 2011 and 2012. One tomato variety namely Rosa was planted in the green house on April, 21 st and transplanted to the experimental field on May, 11 and 15th of 2010 and 2011, respectively. The experimental area was 1/6 Feddan divided into seven plots. Each plote (80 $\mathrm{m}^{2}$ )was divided into three replicates. The normal agricultural practices of growing were done usual.

Six control treatments were used in the two tested seasons (four bio-treatments and two chemical insecticides), added to one untreated plot. Spraying treatments was started after one month from transplanting in the experimental field using $\mathrm{cp}_{3}$ Knapsack. Spraying was applied twice a week until the tomato leaflets dryness.

Leaflet samples were taken randomly after twenty four hours from applying treatments.A sample was consisted of 
108 leaflets/3 replicates for each treatment. Samples were transferred to the laboratory to examine numbers of infested leaflets, mines and estimating the infestation percentages.

Fruit samples were collected weekly for one month.Three plants were selected randomly to pick up its fruits for each treatment. Mean tomato fruit yield, infested tomato fruits by Tuta absoluta larvae and infested tomato fruits by the tomato leafminer larvae\& fungi were evaluated.

\section{Tested materials.}

\subsection{Bio-treatments:}

\subsubsection{Microbial isolations:}

2.1.1. (a). Bacillus subtilis.

2.1.1. (b). Pseudomonas Fluorescence

2.1.1. (c). Trichoderma viride

\subsubsection{Bacterial insecticide.}

\subsection{2. (a). Spinosad:}

Spinosad dust $(0.125 \%$ WP) Dow AgroSciences product is a mixture of the two most active naturally occurring metabolites of the soil bacterium Saccharopolyspora spinosad. Spinosad is a mixture of about $85 \%$ Spinosyn A and $15 \%$ Spinosyn D.,structurally, these compounds are macrolides and contain an unique tetracyclic ring system to which two different sugars are attached(AbdelMageed,2008).

Spinosyn A, Empirical Formula C41H65NO10;MW 731.98.

Spinosyn D, Empirical Formola C42H67NO10; MW 746.00 .

\subsection{Chemical insecticides:}

\subsubsection{Profenofose:}

Common name is Selecron $(72 \%$ EC).It is an organophosphorus compound applied at rate of $100 \mathrm{~cm} / 100 \mathrm{~L}$ water.

\subsubsection{Aphox:}

The common name is Pirimicarb $(50 \% \mathrm{DG})$. It is a carbamate compound applied at rate of $250 \mathrm{gm} / 100 \mathrm{~L}$ water.

The insecticides used against all leaf miners in Egypt are also used to control the white flies and aphids which have systemic effect.

\section{Laboratory studies:}

\subsection{Preparation of microbial inocula:}

The microorganisms were recultured on suitable liquid media, potato dextrose broth (PDB) for fungi or nutrient broth (NB) for bacteria in flasks of $500 \mathrm{ml}$ capacity containing 200 $\mathrm{ml}$ medium. In case of fungus, cultures were incubated at $28^{\circ}$ C for 10 days. Spore suspension of Trichoderma isolate was sieved through double cheesecloth and hand homogenized and counts of spores were adjusted to $10^{6} \mathrm{spore} / \mathrm{ml}$ using hemocytometer. In cases of bacterial isolates, cultures were incubated at $28^{\circ} \mathrm{C}$ for 5 days in shaking incubator $(140 \mathrm{r} /$ min.) and cell suspension was adjusted to $10^{8}$ cell $/ \mathrm{ml}$. Bacillus subtilis, Pseudomonas fluorescence and Trichoderma viride isolated by El-Khateeb (2004) were kindly obtained.

\subsection{Procedure of application:}

Cultures were amended with calculated aliquots of an adhesive surfactant (New-Film, 1265 registered by ministry of Agric., Egypt) as recommended (30 ml/100 L) and hand homogenized before fine spraying onto the upper and the lower leaf surfaces of plant cotyledons until runoff. Plants, sprayed with sterilized tap water (likely amended with the adhesive surfactant), served as check treatment (control).

\subsection{Identify the pathogens.}

During the examination of tomato leaflets samples picked from plots treated by Trichoderma viride, some larvae were found showing symptoms of microbial disease. Larvae had soft bodies, static, cuticle color was close of brown. The pathogen was isolated from the diseased larvae to be defined.

\section{Results and discussion}

\section{The effect of some bio-treatments used to control the tomato leaf miner; Tuta absoluta (Meyrick) infesting tomato plants.}

Table (1) and figure (1) showed the number of infested tomato leaflets, the number of mines and the infestation percentages in the two successive seasons; 2011and 2012 according to the four bio- treatments tree isolations and one bioinsecticide) and two chemical insecticides. In the first season, the Tricoderma sp. isolate gave the least infestation (167, 195, and 21.9\% resp.) followed by Spinosad (233, 301 and $30.8 \%$ ), the Bacillus subtilis isolate (246, 338 and $32.9 \%$ resp.), the Pseudomonas Fluorescence isolate (334, 475 and $44.2 \%$ resp.). In the latest ranking, Aphox (423, 559 and 55.9\% resp.) and Prohpenofos(436, 562 and 57.7\%). The nearby trend was recorded in the second season 2012. Since the lowest infestation level related with Tricoderma viride treatment (198, 222 and 26.2\% resp.).The middle infestation levels related with Bacillus subtilis, Spinosad.and Pseudomonas Fluorescence treatments (261, 351 and $34.5 \%$ $\& 270,383$ and $35.7 \%$ \& 321, 466 and $42.4 \%$ resp.). While Aphox and Prophenofos recorded the highest infestation levels $(384,839$ and $72.2 \% \& 391,534$ and $51.7 \%$ resp.).

Generally, the chemical insecticides Aphox and prophenofos recorded greater infestation than microbial treatments (Tricoderma viride, Bacillus subtilis, Pseudomonas Fluorescence) and Spinosad. While the greatest values were obtained in check during the two seasons 2011 and 2012 (614, 889 and $81.2 \%$ \& 546, 839 and $72.2 \%$ resp.) Statically analysis showed significant differences among the tested treatments in their efficiency of T. absoluta control.

Figure (1) showed one of the diseased larvae that was obtained during the examination of samples. Leaflet samples taken from plants treated with Trichoderma viride isolate. 
Table (1): The effect of the four bio- treatments compared to chemical insecticides against T. absoluta during 2011 and 2012 seasons.

\begin{tabular}{|c|c|c|c|c|c|c|}
\hline Seasons & & 2011 & & & 201 & \\
\hline Treatments & Inf. leaflets & mins. No. & Infestation \% & Inf. leaflets & mins. No. & Infestation \% \\
\hline Bacillus subtilis & $246^{\mathrm{d}}$ & $338^{\mathrm{d}}$ & $32.9^{\mathrm{e}}$ & $261^{\mathrm{d}}$ & $351^{\mathrm{d}}$ & $34.5^{\mathrm{d}}$ \\
\hline Spinosad & $233^{\mathrm{d}}$ & $301^{\mathrm{d}}$ & $30.8^{\mathrm{e}}$ & $270^{\mathrm{d}}$ & $383^{\mathrm{d}}$ & $35.7^{\mathrm{d}}$ \\
\hline Pseudomonas Fluorescence & $334^{\mathrm{c}}$ & $475^{\mathrm{c}}$ & $44.2^{\mathrm{d}}$ & $321^{\mathrm{c}}$ & $466^{c}$ & $42.2^{\mathrm{c}}$ \\
\hline Tricoderma viride & $167^{\mathrm{e}}$ & $195^{\mathrm{e}}$ & $21.9^{\mathrm{f}}$ & $198^{\mathrm{e}}$ & $222^{\mathrm{e}}$ & $26.2^{\mathrm{e}}$ \\
\hline Prophenofos & $436^{\mathrm{b}}$ & $534^{\mathrm{b}}$ & $51.7^{\mathrm{c}}$ & $391^{\mathrm{b}}$ & $562^{\mathrm{b}}$ & $51.7^{\mathrm{b}}$ \\
\hline Aphox & $423^{\mathrm{b}}$ & $559^{\mathrm{b}}$ & $55.9^{\mathrm{b}}$ & $384^{\mathrm{b}}$ & $516^{\mathrm{b}}$ & $50.8^{\mathrm{b}}$ \\
\hline Control & $614^{\mathrm{a}}$ & $889^{a}$ & $81.2^{\mathrm{a}}$ & $546^{\mathrm{a}}$ & $839^{\mathrm{a}}$ & $72.2^{\mathrm{a}}$ \\
\hline
\end{tabular}

The values were an average of three determinations.

Values followed by the same letter in column are not significantly different at $\mathrm{p}<0.01$.

$\mathrm{a}, \mathrm{b}, \mathrm{c}, \mathrm{d}, \mathrm{e}, \mathrm{f}$ and $\mathrm{g}$ : comparison of means by treatments.

Table (2): The percentages of yield and infested tomato fruits under tested treatments in 2012 season.

\begin{tabular}{|c|c|c|c|c|c|c|c|}
\hline \multirow{3}{*}{ Treatments. } & \multirow{3}{*}{ yield/12 plants } & \multirow{3}{*}{$\begin{array}{c}\text { Average } \\
\text { yield/plant }\end{array}$} & \multirow{3}{*}{$\begin{array}{c}\% \text { yield } \\
\text { increasing }\end{array}$} & \multicolumn{4}{|c|}{ Infested fruits by } \\
\hline & & & & \multicolumn{2}{|c|}{ Larvae } & \multicolumn{2}{|c|}{ Larvae + fungi } \\
\hline & & & & Total & $\%$ & Total & $\%$ \\
\hline Bacillus subtilis & $100^{\mathrm{b}}$ & $8.33^{\mathrm{b}}$ & $38.89^{\mathrm{b}}$ & $37^{\mathrm{b}}$ & $37.00^{\mathrm{e}}$ & $18^{\mathrm{d}}$ & $18^{\mathrm{f}}$ \\
\hline Spinosad & $97^{\mathrm{b}}$ & $8.08 b^{c}$ & $34.72^{\mathrm{c}}$ & $37^{\mathrm{b}}$ & $38.14^{\mathrm{d}}$ & $21^{\mathrm{b}}$ & $21.65^{\mathrm{de}}$ \\
\hline Pseudomonas Fluorescence & $91^{\mathrm{c}}$ & $7.58^{c}$ & $26.39^{\mathrm{d}}$ & $34^{\mathrm{c}}$ & $37.36^{\text {de }}$ & $19^{\text {cd }}$ & $20.88^{\mathrm{e}}$ \\
\hline Tricoderma viride & $126^{\mathrm{a}}$ & $10.50^{\mathrm{a}}$ & $75.00^{\mathrm{a}}$ & $31^{\mathrm{d}}$ & $21.38^{\mathrm{f}}$ & $13^{\mathrm{e}}$ & $10.32^{\mathrm{g}}$ \\
\hline Prophenofos & $78^{\mathrm{d}}$ & $6.5^{\mathrm{d}}$ & $8.33^{\mathrm{e}}$ & $35^{\mathrm{c}}$ & $44.87^{\circ}$ & $18^{\mathrm{d}}$ & $22.78^{\mathrm{c}}$ \\
\hline Aphox & $72^{\mathrm{e}}$ & $6^{\mathrm{e}}$ & $0.00^{\mathrm{f}}$ & $34^{\mathrm{c}}$ & $47.22^{\mathrm{b}}$ & $20^{\mathrm{bc}}$ & $27.78^{\mathrm{b}}$ \\
\hline Control & $72^{\mathrm{e}}$ & $6^{\mathrm{e}}$ & $0.00^{\mathrm{f}}$ & $40^{\mathrm{a}}$ & $55.56^{\mathrm{a}}$ & $24^{\mathrm{a}}$ & $33.33^{\mathrm{a}}$ \\
\hline
\end{tabular}

The values were an average of three determinations.

Values followed by the same letter in column are not significantly different at $\mathrm{p}<0.01$.

a, b, c, d, e, f and g: comparison of means by treatments.

The pathogen was isolated and defined by Microbiology Laboratory,Botany Department in Faculty of agriculture at Kafer elsheikh University. The pathogen was defined as Trichoderma viride.

These findings agreed with Lietti et. al., 2005 they reported that some populations of T. absoluta have developed resistance to organophosphate and pyrethroid pesticides. Gonzalez-Cabrera et. al., 2011 mentioned that newer compounds such as spinosad and Bacillus thuringiensis have demonstrated some efficacy in controlling European outbreaks of this moth.

\section{Evaluating the percentages of infested tomato fruits by $T$. absoluta larvae in the tested treatments.}

Data presented in Table (2) indicated that the maximum yield of tomato fruits during four weeks was took place in Tricoderma viride treatment (126 fruits/12 plants.) which increased by $75 \%$ over the check. While the minimum yield was occurred in Aphox treatment (72 fruits/12 plants)that equaled with check. The tomato fruits yield resulted from Bacillus subtilis, Spinosad and Pseudomonas Fluorescence treatments were occupied intermediate values $(100,97$, and 91 fruits/12 plants resp.).

Concerning the infested tomato fruits percentages with $T$. absoluta larvae in season 2011 were arranged in ascending

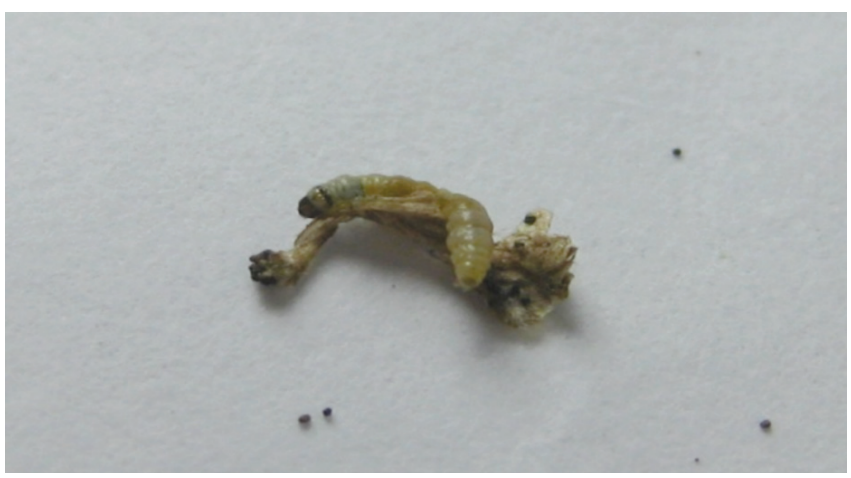

Fig.(1): Infected larva after Trichoderma viride treatment.

order as follows; $21.38,37.00,37.36,38.14,44.87,47.22$ and $55.56 \%$ in Tricoderma viride, Bacillus sutilis, Pseudomonas Fluorescence. Spinosad Prophenofos, Aphox treatments and finally check respectively.

During the examination of infested fruits by T. absoluta larvae, Found that a large number of them infected with Rhizoctonia solani fungus that causes Rhizoctonia soil rot disease. Symptoms are alternating light-and dark-colored zonate bands on fruit surfaces (figs.3 and 4). The infected tomato fruits must had a hole of tomato leaf miner larva (fig.2).The infected tomato fruits with fungus ranged between 41.94 and $60.00 \%$ from the total of infested tomato fruits with $T$. absoluta larvae according to the different treatments. The highest infestation percentage was obtained by spraying 
Aphox $(58.82 \%)$ then the control $(60.00 \%)$, while the lowest infestation percentage was achieved by using Tricoderma viride isolation which was $41.94 \%$ (Table 2 and Fig.2).

The previously data can be interpreted that the tomato leaf miner larvae speed up the entry of Rhizoctonia solani fungus. So, the real danger of Tuta absoluta lies in its impact on quantity and quality of the tomato crop.

Fungi of the genus Trichoderma are important biocontrol agents (BCAs) of several soil borne phytopathogens (Benitez et al. 2004). The biocontrol by fungal species of the Trichoderma genre, of root and crown rot caused by $R$. solani, are being used as an alternative to chemical fungicides (Papavizas, 1985; Limon et al. 1999; Rey et al. 2001).

Statistical analysis for yield increasing percentages showed significant differences among all experimented treatments. While the infested tomato fruits by T. absoluta larva and by $T$. absoluta larva with fungi revealed that Trichoderma viride differ highly significant than the others.

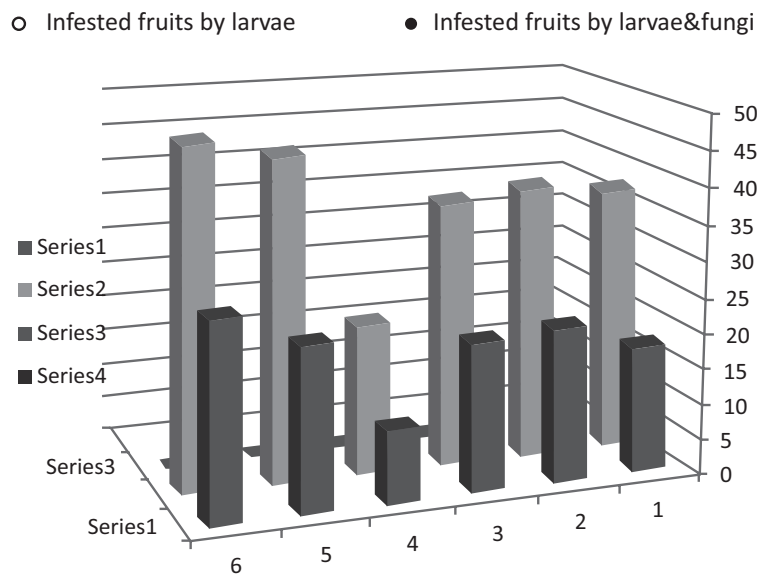

Fig. (2): The percentages of infested tomato fruits by T. absoluta larvae and T. absoluta larvae and fungi in the tested treatments
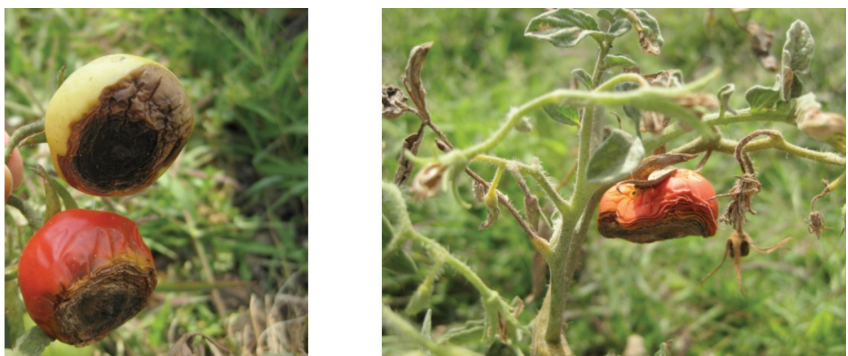

Fig. (3 and 4): Tomato fruits infected with Rhizoctonia soil rot disease.

\section{References}

Abdel-Mageed, A. M. (2008). Studies on certain pests of potato. M.SC.thesis, Fac. Agric.,Tanta Univ.

BENÍTEZ, T.; RINCÓN, Ana M.;LIMÓN M. C. and CODON A. (2004). Bioncontrol mechanisms of Trichoderma strains. International Microbiology, 7(4):249-260.

Campbell, C.D.; J.F. Walgenbach and G.C.Kennedy (1991). Effect of parasitoids on lepidopterous pests in insecticide-treated and untreated tomatoes in Western Northe Carolina. J. Econ. Entomol.84:1662-1667.

El-Khateeb, Nagwa M. M. (2004). Pathological studies on Sclerotium cepivorum the causal agent of onion white rot and its control by biological agents. M. SC. Thesis, Fac. Agric. Tanta Univ.,Egypt. 99 pp.

Gonzalez-Cabrera J, O. Molla, H. Monton and A. Urbaneja (2011). Efficacy of Bacillus thuringiensis (Berliner) for controlling the tomato borer, Tuta absoluta (Meyrick) (Lepidoptera: Gelechiidae). Biocontrol 56, 71-80.

Lietti, M. M. M., E. Botto, and R. A. Alzogaray (2005). Insecticide Resistance in Argentine Populations of Tuta absoluta (Meyrick) (Lepidoptera: Gelechiidae). Neotropical Entomology 34(1):113-119.

LIMON, M. Carmen; PINTOR-TORO, José A. and BENÍTEZ, T. (1999). Increased antifungal activity of Trichoderma harzianum transformants that overexpress a $33-\mathrm{kDa}$ chitinase. Phytopathology, 89(3): 254-261.

Marcela, M.M.; E. Botto and R.A. Alzogray (2005). Insecticide resistance in Argentine populations of T. absoluta (Merick) (Lepidoptera:Gelechiidae).Neotrop. Entomol.34(1).

PAPAVIZAS, G.C. (1985). Trichoderma and Gliocladium: Biology, ecology, and potential for biocontrol. Annual Review of Phytopathology, 23: 23-54.

REY, M.; DELGADO-JARANA, J. and BENÍTEZ, T. (2001). Improved antifungal activity of a mutant of Trichoderma harzianum CECT 2413 which produces more extracellular proteins. Applied Microbiology and Biotechnology,55(5) : 604-608.

Siquira, H.A.A.; A. Alvaro; R.N.C. Guedes and M.S. Picanca (2000a). Insecticide resistance in populations of Tuta absoluta (Lepidoptera:Gelechiidae). Agric.Forest. Entomol. 2:147-153.

Siquira, H.A.A.; R.N.C.Guedes and M.S. Picanca(2000b). Cartap resistans and synergism in populations of $\mathrm{T}$. absoluta (Lepidoptera:Gelechiidae). J.Appl.Ent.124:233-238.

Walgenbach, J.F.; R.B. Leidy and T.J. Sheets(1991). Persistance of insecticides on tomato foliage and implication for control of tomato fruits worm (Lepidoptera:Noctuidae). J.Econ. Entomol.84:978-986.

Weinzierl, R., andT. Henn (1989). Alternatives in insect management: Microbial insecticides. Cooperative Extension, University of Illinois, Circular 1295. 12 pp. 